\title{
Test Of Bio-Activator Model with Natural Zeolite from South Sulawesi As Filter Media and Adsorbents Heavy Metal $\mathrm{Pb}, \mathrm{Ni}$, and $\mathrm{Cu}$
}

\author{
Sukmasari Antaria ${ }^{1}$, Mary Selintung ${ }^{1}$, Muh. Saleh Pallu ${ }^{1}$, and Mukhsan Putra Hatta ${ }^{1}$
}

\begin{abstract}
The purpose of this study is how the characterization of natural zeolite South Sulawesi and how the ability of zeolite as filter media and adsorbents to reduce the heavy metal lead ( $\mathrm{Pb})$, Nickel $(\mathrm{Ni})$ and Copper $(\mathrm{Cu})$ in the raw water. Zeolites in activation, given the warming that is: $100^{\circ} \mathrm{C}, 200^{\circ} \mathrm{C}, 300^{\circ} \mathrm{C}$, and $400^{\circ} \mathrm{C}$, then in the characterization by $S E M$ and $X R D$. Subsequently smoothed with a 170 mesh size ( $3 \mathrm{~mm}$ ), and weighed each one weighing 50 grams and incorporated into any model of Bio - Activators, respectively on the tube , 2, 3 and 4. Raw water that has been injected with 5 ppm Pb, Ni, Cu heavy metal inserted into the reservoir, then piped or for running into the model to test the ability of zeolite as filter media and adsorbents . Results if the water was tested by means of AAS (Atomic Absorption Spectroscope), instrument test results obtained from the numbers the actual decrease in the concentration and absorbance. Results actual dcrease in the concentration and adsorbance for each heavy metals $\mathrm{Pb}$, Ni and $\mathrm{Cu}$ are : -0.2119, -0.1112, and -0.2902. Model analysis is the method of Langmuir and Freudlich. This result is expected to provide new information about the characteristics of natural zeolite South Sulawesi and produced water treatment models are inexpensive and easy to obtain.
\end{abstract}

Keywords—Zeolite South Sulawesi, Bio-Activator Model, Heavy Metal Lead (Pb), Nickel (Ni), Copper (Cu), Raw Water.

\section{INTRODUCTION}

$\mathrm{T}$ he availability of clean water or clean water services in Indonesia is still low. A leading provider of clean water PAM (Drinking Water Company) or PDAM (Regional Water Company) is only capable to supply the needs in the cities alone with also a small quantity of water. Most part of the people who are not reached by the water services generally use ground water or surface water for their daily life proposes. The water which is consumed by the public mostly not yet eligible to drink according to the Regulation of the Minister of Health of the Republic of Indonesia.to bind heavy metals and toxic elements contained in raw water, require expensive equipments, facilities and materials. However, in Sangkaropi and Kasinggiran hamlet,n the village of Sangkaropi, Toao and Mendilla, sub-districtof Sa'dang Balusu, North Toraja and Luwu Regency, South Sulawesi, mineral zeolite is found as natural ion exchanger that ischeap and easy to find. The ability of zeolite by many researchers is used as a versatile mineral such as; dehydration, adsorbent and molecule filtration, catalyst and ion exchanger.

Based on the above background description the aim of this study can be formulated as follows :

a. How does the ability of South Sulawesi natural

Zeolite as filtration media in the raw water.

b. How is test results processing model of water quality.

The aim of study is to examine the ability of South Sulawesi natural Zeolite as filtration media in the raw water and to perform test results processing model of water quality.

${ }^{1}$ Sukmasari Antaria, Mary Selintung, Muh. Saleh Pallu, and Mukhsan Putra Hatta are with Departement of Civil Engineering, Universitas Hasanuddin, Makassar, Indonesia.

E-mail:Sukmasari.Antaria@yahoo.co.id;maryselintung@yahoo.com; salehpallu@hotmail.com; Mukhsan_hatta@yahoo.com.
According to Sennang (1995), by 2020 Indonesian population is estimated to grow and reach the $\mathrm{kl}$ 262.409.000 people or South Sulawesi population is expected to reach kl 9.800 .000 people or more and of course along with an adequate water supply. The required daily water will continue to increase both terms of quantity and quality and type of use. The fulfillment of water to society will increasingly depend on the quality of Watershed (DAS) the upper reaches as the catcher, the depository and a regulator of water. The results of the Research Center for water resources about the reservoir water quality in Indonesia for 1996-2010 period including Bili-Bili reservoir in South Sulawesi experiencing high level of sedimentation. The dam suffered water turbidity ranging from 29,000-152,000, exceeds the threshold, i.e. 6000 NTU (Nhepelometric Turbidity units). (SEPLH Journal in the Hamzah, 2010).

Based on Rahman and Hartono (2004), that a decent of clean fresh water to drink for society consumption is increasingly scarce in urban areas. Conventional filtering which has been used is simply the processof disinfection only and streamed directly to consumers. The surface water or ground water that is used daily often contain toxic or heavy metal elements.

According to Nusa and Satmoko (2008) the main problems that are still encountered in the clean water supply in Indonesia are :

a. Service levels are still low.

b. Fluctuating of raw water discharge in the rainy and dry season.

c. The used technology for processing is less in accordance with the conditions of the decreasing raw water quality.

As drinkable water, it has a specific standard requirements i.e. requirements of physical, chemical and bacteriological requirements, in which the requirement is one unit. If there is only one parameter that does not qualify then the water is undrinkable. This is according to the Regulation of the Minister of Health Republic of Indonesia (ID: 492/MenKes/Per/IV/2010). 
According to Joko (2010), there are 2 (two) kinds of processes that arecommonly used in water processing all this time, namely :

a. Complete processing; Here raw water undergoes complete processing; physical, chemical and bacteriologicalprocessing. This processing is conducted for raw water from the muddy/dirty river.

b. Part process; raw water only undergoes a process of chemical processing and/or bacteriological treatment.

On complete processing process there are 3 (three) processing stages, namely :

a. Physical processing; to reduce/remove coarse dirt, mud, and sand allowance, reduce substances found in the water that will be processed. Physical processingis performed without additional chemical substance.

b. Chemical processing; to help further processing, i.e. additional alum so that reduce the existing turbidity.

c. Biological processing; to kills/destroy bacteria especiallydisease-causing bacteria contained in water e.g.; coliform bacteria that cause

d. abdominal pain. One of its processing is performed by additional disinfectant (alum).

\section{A. Material Zeolite}

Natural zeolite has an absorbent character which can absorb metal ion minerals that are contained in raw water (Srihapsari, 2006). Furthermore Sujarwadi in Sinly (2007) suggested that commonly zeolite molecule formula is $\mathrm{M}_{\mathrm{x} / \mathrm{n}}\left[\left(\mathrm{AlO}_{2}\right)_{\mathrm{x}}\left(\mathrm{SiO}_{2}\right)_{\mathrm{y}}\right] \mathrm{m} \mathrm{H}_{2} \mathrm{O}$. Zeolite utilization for various applications especially was directed to increasing effectiveness and efficiency of industrial aspect as well as its environment pollution process.

According to Department of Energy and Mineral Resources (2001), composition natural of zeolite consisting of, alumino silicate hydrate compounds and alkali metal elements with physical and chemical properties such as high degree of hydration, a low density space, the ability to exchange cations, channel molecules that are uniform in hydrated crystals, the ability of the catalyst and the conductivity of the electricity.

According to Rosdiana (2006), the activation is a process to raise adsorption capacity, thus obtained the desired properties according to its use. Zeolite activation purpose is to produce more surface area through the formation of a porous structure and also to eliminate pollutant compounds. Zeolite activation is performed by heating, additional acid, and additional base. The acid which are commonly using are sulfuric acid $\left(\mathrm{H}_{2} \mathrm{SO}_{4}\right)$ and chloride acid ( $\mathrm{HCl})$. While $\mathrm{NaOH}$ is used as a base.

\section{B. Potential Zeolite In South Sulawesi}

According to The Department of Energy and Mineral Resources of South Sulawesi Province (2001) that the zeolite can be used in many different areas, namely :

a. As a fertilizer for agriculture;

b. As an added ("additive") animal feed; As an absorbent material ("adsorption") ammonium and other toxins in the soil, or remediation of former mine lands, as well as a "filter" of the pollutant elements on installation of water processing system.

\section{METHOD}

A. Preparation Research.

a. Sampling of natural zeolites in North Toraja Regency.

b. Sampling of raw water in the river Jeneberang.

B. Implementation Research.

1) Zeolite Characterization.

a. XRD ( X-ray Difraction ) MINIFLEX Rigaku Type II

i. Zeolite samples in activation, given eacheating temperature $(\mathrm{T}): 100{ }^{\circ} \mathrm{C}, 200{ }^{\circ} \mathrm{C}$, $300{ }^{\circ} \mathrm{C}$, and $400{ }^{\circ} \mathrm{C}$.

ii. Zeolite that has been prepared with the activation of a size of $1.5 \mathrm{~cm}$.

iii. Further samples are already in preparation put in XRD.

b. SEM (Scanning Electron microscop), Type 3 VEGA Tescan

i. Zeolite samples are already in the activation crushed or mashed with a size of $1 \mathrm{~cm}$, the samples in the dry state.

ii. then the zeolite samples were prepared and incorporated into coatings to (in) gold coat that unburned samples electron.

iii. After coating the samples included in the SEM images and elements to be taken.

2) Model Test Water Treatment.

a. Zeolite samples that have been taken in activation with heating $(\mathrm{T}): 100^{\circ} \mathrm{C}, 200^{\circ} \mathrm{C}, 300^{\circ} \mathrm{C}$ and $400^{\circ}$ C.

b. Then smoothed with a sample size of 170 mesh or with a size of $3 \mathrm{~mm}$.

c. Zeolite samples were weighed with digital scales weighing 50 grams, and then incorporated into models of water treatment is to tabung 2, 3 and 4, with a single media.

d. 8 liter reservoir is filled with water that has been injected with heavy metals $\mathrm{Pb}, \mathrm{Ni}$ as much as 5 ppm.

e. Then the water flows or for running into the model, starting from the contact time to produce 1 liter of clean water.

f. Processed water tested with test equipment Atomic Absorption Spectrophotometer (AAS), Type SHIMADSU AA-7000, from the test results, obtained figures which decrease the actual concentration and absorbance.

3) Heavy Metal Content Test Pb, Ni At River Raw Water Jeneberang.

The procedure is as follows :

a. Water sampling at the water entering in to the intake dam, then measured the $\mathrm{pH}$.

b. Sampling of water at the dam is water that is in the middle of the dam, measured $\mathrm{pH}$.

c. Sampling of water out of the dam, its $\mathrm{pH}$ was measured.

Of the three water samples were tested by mean of AAS and WATER TESKIT DITECH WA1.510. to measure; $\mathrm{pH} / \mathrm{ORP}, \mathrm{DO}, \mathrm{CD} / \mathrm{TDS}$ Meter. 


\section{RESULT AND DISCUSSION}

Results characterization of natural zeolite South Sulawesi, using XRD instrument, obtained as in Figure 4 , the variation of heating; $100^{\circ} \mathrm{C}, 200^{\circ} \mathrm{C}, 300^{\circ} \mathrm{C}$ and $400^{\circ} \mathrm{C}$

Absorbance same regression equation Lead $(\mathrm{Pb})$, for each variation $100^{\circ} \mathrm{C}, 200^{\circ} \mathrm{C}, 300^{\circ} \mathrm{C}$ and $400^{\circ} \mathrm{C}$. By looking at the results in the table 6 above that the warming $300^{\circ} \mathrm{C}$, decreasing the concentration of the most effective is -0.2119 with a time of 180 seconds. By looking at the results in the table 7 above that the warming $200^{\circ} \mathrm{C}$, decreasing the concentration of the most effective is -0.1112 with a time of 180 seconds. By looking at the results in the table 8 above that the warming $200^{\circ} \mathrm{C}$, decreasing the concentration of the most effective is -0.2902 with a time of 180 seconds.

Research Raw Water Samples is using water samples from three locations namely the water of the Jeneberang River. Laboratory examination is conducted to examine heavy metal contain level. The laboratory experiments using pure water has been given by additional content of heavy metals such Lead $(\mathrm{Pb})$, Nickel $(\mathrm{Ni})$, Copper $(\mathrm{Cu})$ shown in table 9 .

\section{CONCLUSION}

Maximum absorption and decrease the actual concentration of heavy metals Lead $(\mathrm{Pb})$ and Nickel (Ni) and Copper $(\mathrm{Cu})$ with South Sulawaesi as natural zeolite filter media in the raw water through laboratory tests obtained the following results:

a. Natural zeolite South Sulawesi as filter media and absorbents in the raw water can adsorb heavy metals Lead $(\mathrm{Pb})$, which is most effective in the activation of the heating value of $300{ }^{\circ} \mathrm{C}$ the decrease in actual concentration and absorbance is -0.2119 .

b. Natural zeolite South Sulawesi as filter media and absorbents in the raw water can adsorb heavy metals Nickel (Ni), which is most effective in the activation of the heating value of $200{ }^{\circ} \mathrm{C}$ the decrease in actual concentration and absorbance is - 0.1112 .

c. Natural zeolite South Sulawesi as filter media and absorbents in the raw water can adsorb heavy metals Copper $(\mathrm{Cu})$, which is most effective in the activation

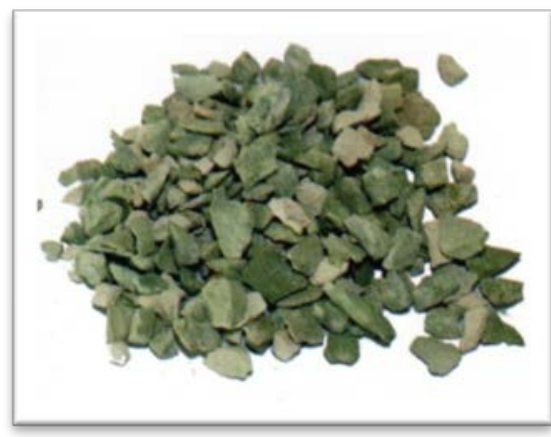

Figure 1. Material Zeolite of the heating value of $200{ }^{\circ} \mathrm{C}$ the decrease in actual concentration and absorbance is - 0.2902.

d. Compound Zeolite in South Sulawesi :

$\mathrm{SiO}_{2} \quad$ : $\quad 62,69 \%-81,03 \%$

$$
\begin{array}{ccc}
\mathrm{Al}_{2} \mathrm{O}_{3} & : & 9,9 \%-19,82 \% \\
\mathrm{Na}_{2} \mathrm{O} & : & 0,12 \%-4,32 \% \\
\mathrm{~K}_{2} \mathrm{O} & : & 0,63 \%-6,88 \% \\
\mathrm{CaO} & : & 0,10 \%-0,22 \% \\
\mathrm{LOI} & : & 1,26 \%-12,62 \%
\end{array}
$$

\section{ACKNOWLEDGEMENT}

This research is my dissertation and supported by the Ministry of Education and Culture Scholarship Indonesia. The second, the third and the fourth authors also grateful for helpful discussions.

\section{REFERENCES}

[1]. A. Rahman and B. Hartono, "Water Filtration With Natural Zeolite To Lower Levels of Iron and Manganese,” Makara Journal, Health, $\quad$ Vol. $\quad 8$ No.1 (http://www.journal.ui.ac.id/upload/artikel/01-filtration waterARahman.pdf), 2004.

[2]. D. Srihapsari, "Use of Natural Zeolite that has been activated with $\mathrm{HCl}$ solution to Absorb Metals Causes of Water Hardness," Chemical Thesis, State University of Semarang, 2006.

[3]. E.P. Sinle "Zeolites As Multipurpose Minerals," http://www.chem-is-try.org/artikel - Chemistry/chemistry material/zeolite - multy-fungtion- Decision Matter of Health of the Republic of Indonesia No 907/ Health Minister/SK/VII/2002 Terms of Safeguarding Drinking Water Quality, 2007.

[4]. I. S. Nusa and Y. Satmoko, "Issues and Strategies in Indonesian Water Supply,” 2008, (http://www.kelair.bppt.go.id publications / books of drinking water.Html).

[5]. Report of Pre-Feasibility Study, "Factory Development of Zeolite in North Toraja and Luwu Regency," Department of Energy and Mineral Resources of South Sulawesi, 2001.

[6]. S. Sennang, "Availability Issues and Challenges the Municipality Water of Ujung Pandang In 2020,” HATHI Ujung Pandang Branch, 1995.

[7]. T. Joko "Production Unit in Water Supply System,” Yogyakarta, Graha Science, 2010.

[8]. Sujarwadi, “Overview About Zeolites,” Development Center of Mineral Technology in Bandung, 1997.

[9]. Sujarwadi, “Overview About Zeolites,” Development Center

[10]. Y.et al. Hamzah.Y.et al, "Publication of Scientific and Research Plan,” Doctoral Program in Civil Engineering Graduate Program Hasanuddin University Vol. 1, page 1- 12, 2010.

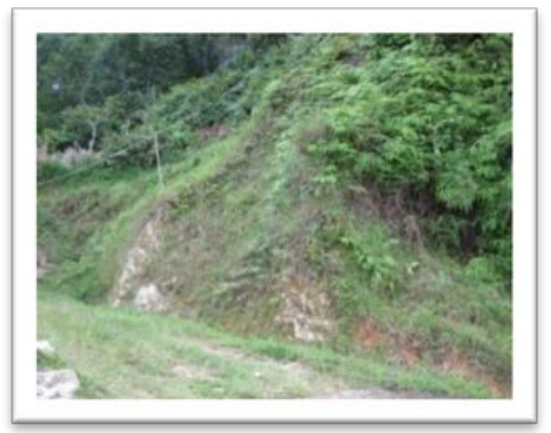

Figure 2. Zeolite Sangkaropi 


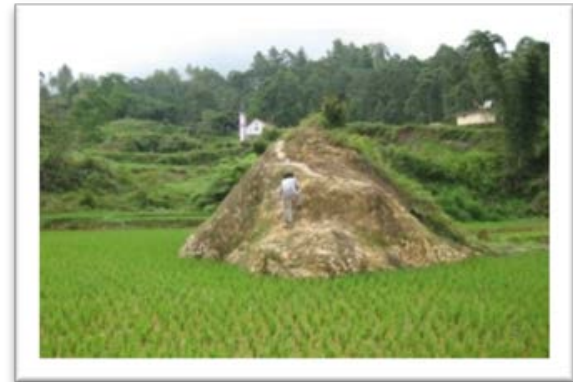

Figure 3. Zeolite Kasinggiran

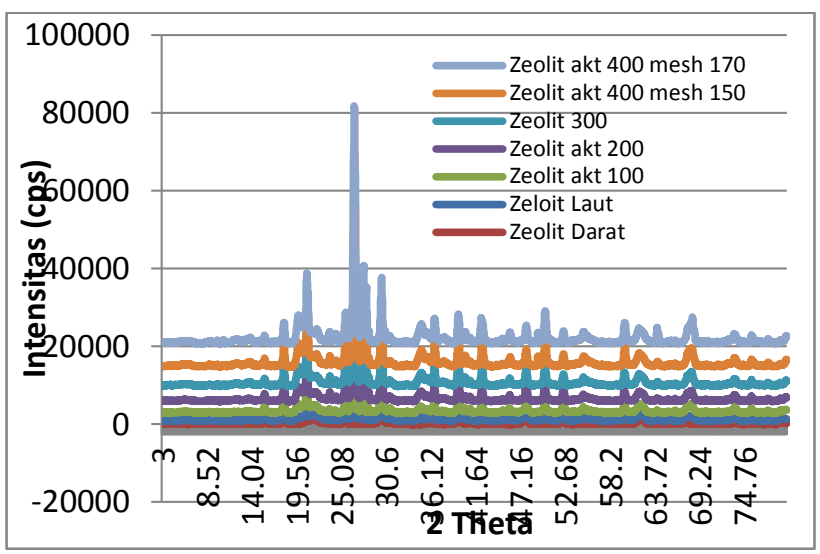

Figure 4. Characterized by X - Ray Difraction type Rigaku Miniflex II
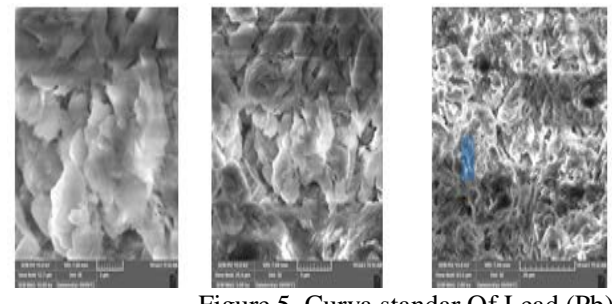

Figure 5. Curva standar Of Lead (Pb)
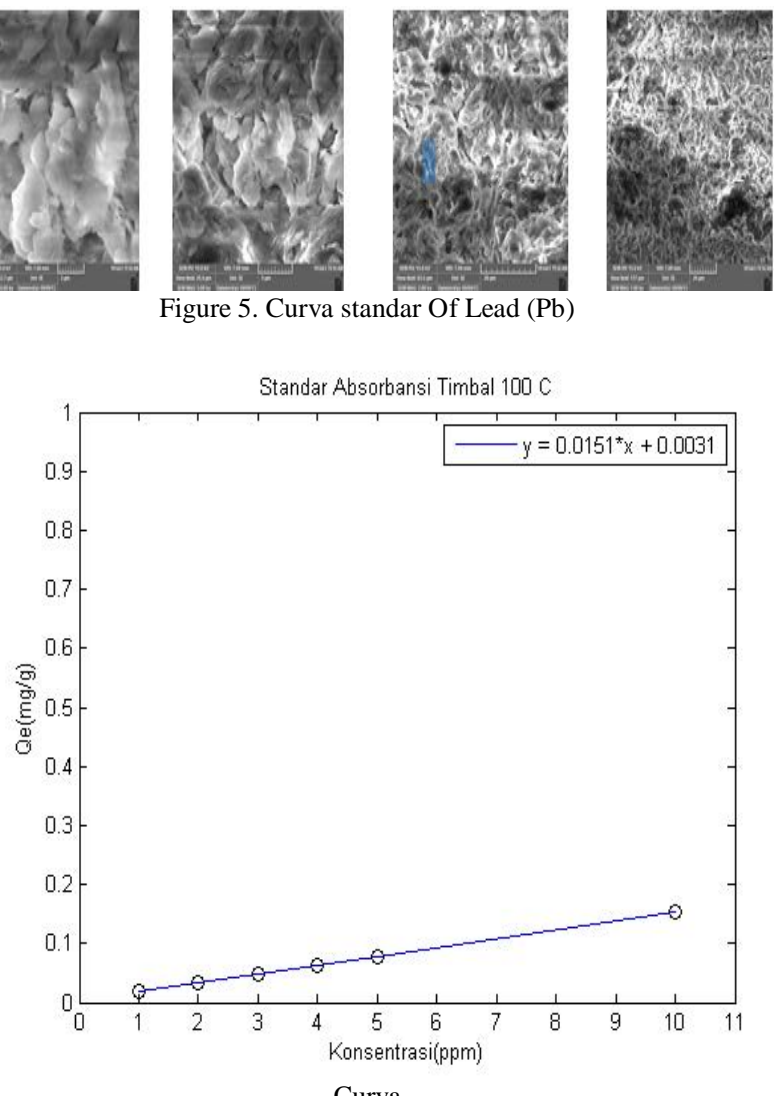

Curva

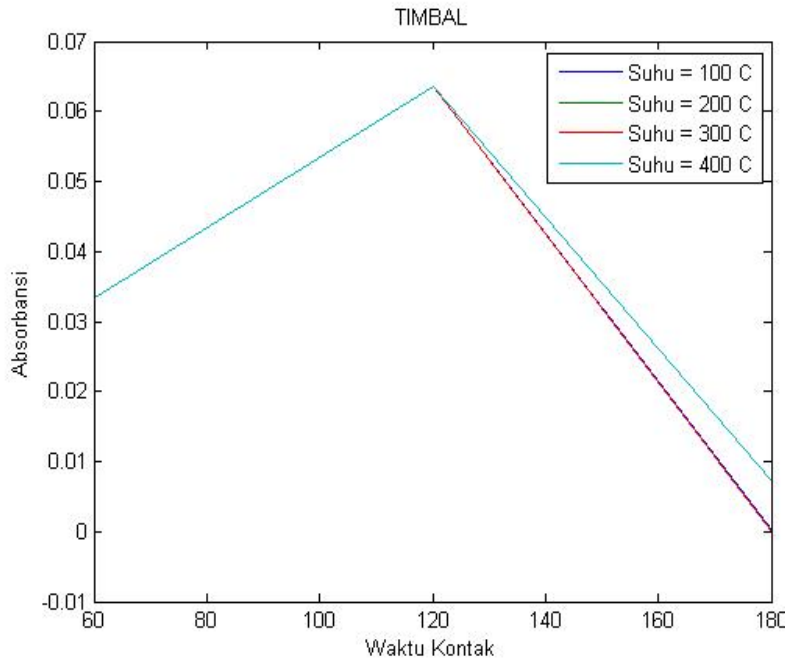

Figure 6. Relationships Absorbance Decrease and The Actual Concentration with Contact Time
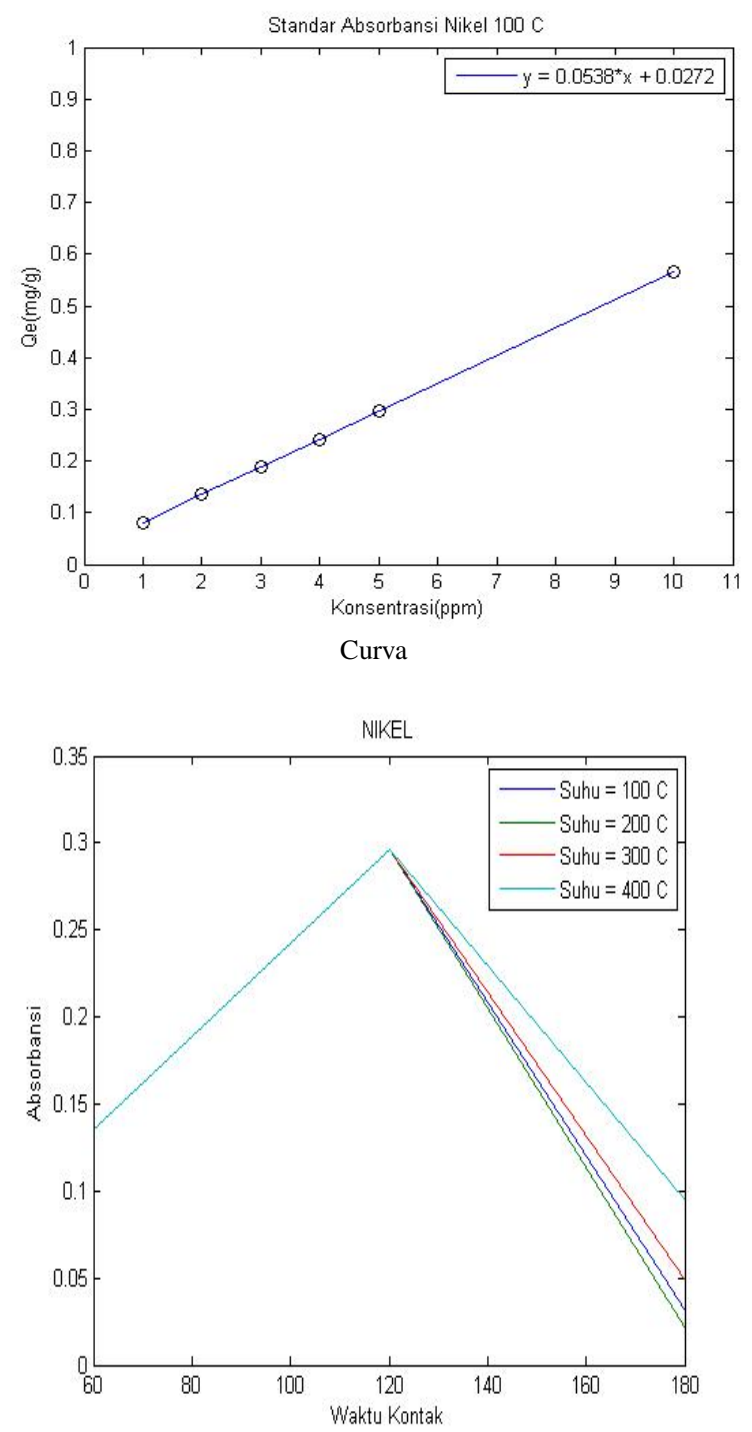

Figure 7. Relationships Absorbance Decrease and The Actual Concentration with Contact Time 

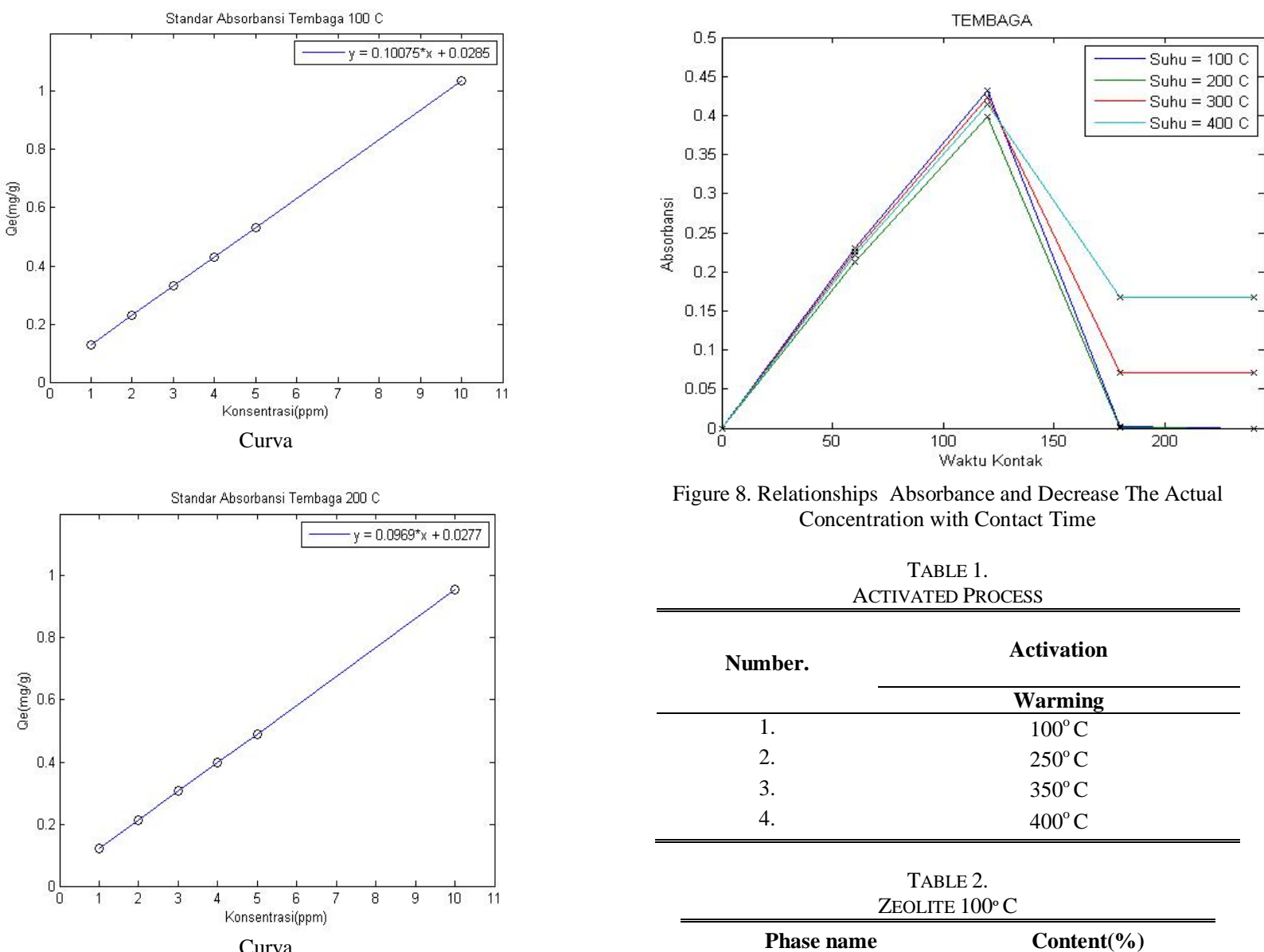

Figure 8. Relationships Absorbance and Decrease The Actual Concentration with Contact Time

TABLE 1.

ACTIVATED PRocess

\begin{tabular}{|c|c|c|}
\hline \multirow{2}{*}{ Number. } & \multicolumn{2}{|c|}{ Activation } \\
\hline & \multicolumn{2}{|c|}{ Warming } \\
\hline 1. & \multicolumn{2}{|c|}{$100^{\circ} \mathrm{C}$} \\
\hline 2. & \multicolumn{2}{|c|}{$250^{\circ} \mathrm{C}$} \\
\hline 3. & \multicolumn{2}{|c|}{$350^{\circ} \mathrm{C}$} \\
\hline 4. & \multicolumn{2}{|c|}{$400^{\circ} \mathrm{C}$} \\
\hline \multicolumn{3}{|c|}{$\begin{array}{c}\text { TABLE } 2 . \\
\text { ZeOLITE } 100^{\circ} \mathrm{C} \\
\end{array}$} \\
\hline Phase & \multicolumn{2}{|c|}{ Content(\%) } \\
\hline Quartz & \multicolumn{2}{|c|}{$90(30)$} \\
\hline Potassium & \multicolumn{2}{|c|}{$3.9(12)$} \\
\hline Zeolite & \multicolumn{2}{|c|}{$5.7(18)$} \\
\hline \multicolumn{3}{|c|}{$\begin{array}{c}\text { TABLE } 3 . \\
\text { ZEOLITE } 200^{\circ} \mathrm{C} \\
\end{array}$} \\
\hline Phase & \multicolumn{2}{|c|}{ Content (\%) } \\
\hline Quartz loy & \multicolumn{2}{|c|}{$2.98(11)$} \\
\hline Muscovi & \multicolumn{2}{|c|}{$71.1(10)$} \\
\hline Zeolite & \multicolumn{2}{|c|}{$25.9(4)$} \\
\hline \multicolumn{3}{|c|}{$\begin{array}{c}\text { TABLE } 4 . \\
\text { ZEOLITE } 300{ }^{\circ} \mathrm{C} \\
\end{array}$} \\
\hline & name & Content (\%) \\
\hline Que & ow, syn & $66.1(15)$ \\
\hline $\mathrm{Mu}$ & te-2M1 & $20(2)$ \\
\hline $\begin{array}{r}\text { Zeolite F (Na } \\
\text { pentaalumo pe }\end{array}$ & $\begin{array}{l}\text { ntasodium tecto- } \\
\text { licate nonahydrate } \\
\end{array}$ & $13.9(6)$ \\
\hline \multicolumn{3}{|c|}{$\begin{array}{c}\text { TABLE } 5 . \\
\text { ZeOLITE } 400^{\circ} \mathrm{C} \\
\end{array}$} \\
\hline & name & Content (\%) \\
\hline Quartz, Syn & & $45(10)$ \\
\hline Albite, ordered & & $26(5)$ \\
\hline Potassium Tecto- $A$ & totrisilicate & $9(3)$ \\
\hline Zeolite Nu-6(2), S & n Dioxide & $2.5(5)$ \\
\hline Muscovite-2M1 & & $14(5)$ \\
\hline Sodalite & & $3.1(7)$ \\
\hline
\end{tabular}




\begin{tabular}{cc} 
Regression Equation : & $y=0,0151 x+0,0031$ \\
\hline \hline Consentrasi $(x)$ & Absorbansce $(y)$ \\
\hline 1 & 0,0182 \\
3 & 0,0333 \\
4 & 0,0484 \\
5 & 0,0635 \\
10 & 0,0786 \\
\end{tabular}

TABLE 6.

ABSORBANCE DeCREASE AND THE ACTUAL CONCENTRATION (PB)

\begin{tabular}{cccc}
\hline $\begin{array}{c}\text { Variations } \\
\text { Activation }\end{array}$ & $\begin{array}{c}\text { Concentration } \\
\text { Actual }\end{array}$ & Absorbance & $\begin{array}{c}\text { Time } \\
\text { Reduction }(\boldsymbol{d} \boldsymbol{t})\end{array}$ \\
\hline $100^{\circ} \mathrm{C}$ & $-0,1987$ & 0,0001 & 180 \\
$200^{\circ} \mathrm{C}$ & $-0,0910$ & 0,0001 & 180 \\
$300^{\circ} \mathrm{C}$ & $-0,2119$ & $-0,0001$ & 180 \\
$400^{\circ} \mathrm{C}$ & 0,2616 & 0,0070 & 180 \\
\hline \hline
\end{tabular}

Regression Equation: $\mathrm{y}=0,0538 x+0,0272$

\begin{tabular}{cc}
\hline \hline Consentrasi $(\boldsymbol{x})$ & Absorbansce $(\boldsymbol{y})$ \\
\hline 1 & 0,0810 \\
2 & 0,1348 \\
3 & 0,1886 \\
4 & 0,2424 \\
5 & 0,2962 \\
10 & 0,5652 \\
\hline
\end{tabular}

TABLE 7.

AbSORBANCE DECREASE AND THE ACtUAL CONCENTRATION (NI)

\begin{tabular}{ccc}
\hline $\begin{array}{c}\text { Variations } \\
\text { Activation }\end{array}$ & $\begin{array}{c}\text { Concentration } \\
\text { Actual }\end{array}$ & $\begin{array}{c}\text { Time } \\
\text { Reduction }(\boldsymbol{d t})\end{array}$ \\
\hline $100^{\circ} \mathrm{C}$ & 0,0688 & 180 \\
$200^{\circ} \mathrm{C}$ & $-0,1112$ & 180 \\
$300^{\circ} \mathrm{C}$ & 0,3978 & 180 \\
$400^{\circ} \mathrm{C}$ & 1,2471 & 180 \\
\hline \hline
\end{tabular}

Regression Equation: $y=0,10075 x+0,0285$

\begin{tabular}{cc}
\hline \hline Consentrasi $(\boldsymbol{x})$ & Absorbansce $(\boldsymbol{y})$ \\
\hline 1 & 0,1293 \\
2 & 0,2300 \\
3 & 0,3308 \\
4 & 0,4315 \\
5 & 0,5323 \\
10 & 1,0360 \\
\hline
\end{tabular}

\begin{tabular}{cc} 
Regression Equation: $\mathrm{y}=0,0927 x+0,0277$ \\
\hline \hline Consentrasi $(\boldsymbol{x})$ & Absorbansce $(\boldsymbol{y})$ \\
\hline 1 & 0,1204 \\
2 & 0,2131 \\
3 & 0,3058 \\
4 & 0,3985 \\
5 & 0,4912 \\
10 & 0,9547 \\
\hline
\end{tabular}

$\frac{\text { Regression Equation : } y=0,09875 x+0,0281}{\text { Consentrasi }(x)}$

\begin{tabular}{ll}
\hline 1 & 0,1269 \\
2 & 0,2256 \\
3 & 0,3244 \\
4 & 0,4231 \\
5 & 0,5219 \\
10 & 1,0156 \\
\hline
\end{tabular}

\begin{tabular}{cc}
\multicolumn{2}{c}{ Regression Equation: $y=0,0969 x+0,027$} \\
\hline \hline Consentrasi $(\boldsymbol{x})$ & Absorbansce $(\boldsymbol{y})$ \\
\hline 1 & 0,1239 \\
2 & 0,2208 \\
3 & 0,3177 \\
4 & 0,4146 \\
5 & 0,5115 \\
10 & 0,9960 \\
\hline \hline
\end{tabular}

TABLE 8.

ABSORBANCE AND DeCREASE THe ACtual CONCENTRATION (Cu)

$\begin{array}{cc}\text { Variations } & \text { Time } \\ \text { Activation } & \text { Concentration Actual } \\ \text { Reduction }(d t)\end{array}$

\begin{tabular}{lll}
\hline $100^{\circ} \mathrm{C}$ & $-0,2541$ & 180 \\
$200^{\circ} \mathrm{C}$ & $-0,2902$ & 180 \\
$300^{\circ} \mathrm{C}$ & 0,4273 & 180 \\
$400^{\circ} \mathrm{C}$ & 1,4489 & 180 \\
\hline \hline
\end{tabular}

TABLE 9.

Metal Content Of WATER SAMPLes $\begin{array}{cccccccc}\begin{array}{c}\text { Jeneberang } \\ \text { River Bili-bili }\end{array} & \begin{array}{c}\text { Result } \\ \text { AAS }\end{array} & \begin{array}{c}\text { Result } \\ \text { AAS }\end{array} & \begin{array}{c}\text { Result } \\ \text { AAS }\end{array} & \text { DO } & \text { DHL } & \text { BOD }_{5} & \text { COD } \\ \text { Dam } & \text { Pb } & \text { Ni } & \text { Cu } & & & & \end{array}$

\begin{tabular}{|c|c|c|c|c|c|c|c|c|}
\hline $\begin{array}{c}\mathrm{pH} \\
(5,8)\end{array}$ & $\begin{array}{l}\text { Water } \\
\text { in the } \\
\text { Dams }\end{array}$ & $\begin{array}{c}-0,001 \\
\text { ppm }\end{array}$ & $\begin{array}{c}+0,000 \\
\text { ppm }\end{array}$ & $\begin{array}{c}+0,000 \\
\text { ppm }\end{array}$ & 9,2 & 114,4 & 1,76 & 2,46 \\
\hline $\begin{array}{c}\mathrm{pH} \\
(56)\end{array}$ & $\begin{array}{l}\text { Water } \\
\text { in the } \\
\text { Middle } \\
\text { Dam }\end{array}$ & $\begin{array}{c}-0,000 \\
\text { ppm }\end{array}$ & $\begin{array}{c}+0,001 \\
\text { ppm }\end{array}$ & $\begin{array}{c}+0,001 \\
\text { ppm }\end{array}$ & 10,8 & 103,9 & 1,36 & 2,10 \\
\hline $\begin{array}{c}\mathrm{pH} \\
(5,5)\end{array}$ & $\begin{array}{l}\text { Water } \\
\text { out the } \\
\text { Dams }\end{array}$ & $\begin{array}{c}-0,001 \\
\text { ppm }\end{array}$ & $\begin{array}{c}+0,001 \\
\text { ppm }\end{array}$ & $\begin{array}{c}+0,001 \\
\text { ppm }\end{array}$ & 9,8 & 128,2 & 1,76 & 3,20 \\
\hline
\end{tabular}

